\title{
Geological characterisation of potential disposal areas for radioactive waste from Risø, Denmark
}

\author{
Peter Gravesen, Merete Binderup, Bertel Nilsson and Stig A. Schack Pedersen
}

Low- and intermediate-level radioactive waste from the Danish nuclear research facility, Risø, includes construction materials from the reactors, different types of contaminated material from the research projects and radioactive waste from hospitals, industry and research institutes. This material must be stored in a permanent disposal site in Denmark for at least 300 years (Indenrigs- og Sundhedsministeriet 2007). The Ministry of
Health and Prevention presented the background and a decision plan for the Danish Parliament in January 2009 (Ministry of Health and Prevention 2009) and all political parties agreed to the plan.

In the beginning of 2011 three studies were presented to the parliament (http://www.im.dk/Aktuelt/Nyheder/ Forebyggelse/2011/Maj/Slutdepot.aspx): (1) A pre-feasibility study for the final disposal of radioactive waste,

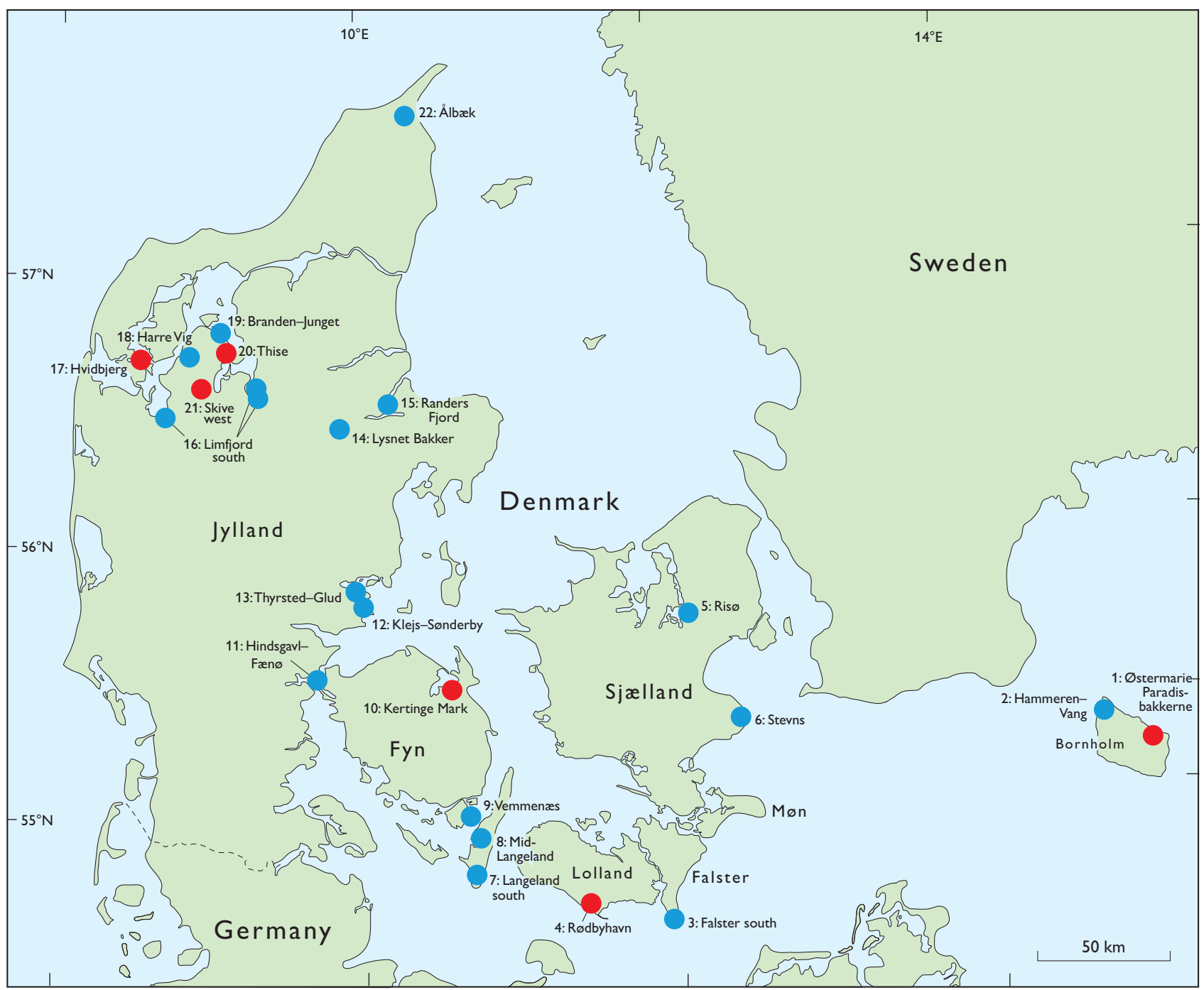

Fig. 1. Map of Denmark showing the location of the 22 selected areas. Red: the six best areas. Blue: the 16 remaining areas. 
(2) a study on radiation doses from the transport of radioactive waste to a future repository and (3) a study on identifying potential disposal areas. The latter study was conducted by the Geological Survey of Denmark and Greenland (GEUS) and the aim was to locate a sediment or rock body with low permeability down to 100-300 $\mathrm{m}$ below the ground surface. The ultimate goal is longterm protection of people and environment by isolating the radioactive waste in a final depository. This goal can be reached by identifying a significant volume of sediments or rocks characterised by a low flow regime and high absorption potential. GEUS was given the task to locate approximately 20 potential disposal areas.

\section{Geological setting and data requirements}

In Denmark, many types of fine-grained sediments and crystalline rocks occur from the ground surface down to a depth of $300 \mathrm{~m}$. Descriptions of these sediments and rocks are based on existing information and include four main types: (1) granite and gneiss on Bornholm, (2) chalk and limestone, (3) fine-grained Palaeogene and Neogene clay and (4) Quaternary clayey till and clay. In Europe, the most studied geological formations for disposal of radioactive waste are clay (Belgium, France, Germany and Switzerland), crystalline rocks (Sweden, Finland and Switzerland) and salt (Germany). Salt diapirs and salt pillows as well as deep-seated basement rocks are not included in the current study.

Several types of existing data were compiled for the preliminary selection of the approximately 20 potential areas as outlined by Indenrigs- og Sundhedsministeriet (2007). The recommendations follow the guidelines of the International Atomic Energy Agency (IAEA 1994, 1999, 2005). The study provides an overview of the distribution of various deposits and tectonic features in Denmark. Tectonic features, the distribution of layers of low permeability and the distribution of fractured sediments and rocks are important for the assessment and selection of areas suitable for disposal of radioactive waste (Gravesen et al. 2010).

\section{Data collection and compilation}

The deposits are described from the ground surface down to a depth of at least $100 \mathrm{~m}$. The description of each area comprises: (1) geological conditions such as general geology, surface geology and profiles, sediment and rock characteristics, tectonic features and structures, seismic activity, geological and structural models, ground stability; (2) hydrogeological conditions such as groundwater characteristics, vulnerable drinking-water supply areas, geo- and hydrochemical conditions; (3) ground-surface conditions: terrain and topography, surface processes, climate and climate changes, restrictions and limitations in connection with protection of nature areas; (4) summary of area conditions with final remarks and literature.

The area descriptions address the following important issues (IAEA 1994, 1999, 2005): (1) The final disposal site should be situated in an area with homogeneous geological conditions. It should be demonstrated that these conditions are found with a high degree of probability at the selected site. As the geological conditions in many parts of Denmark are heterogeneous on both local and regional scales, the goal was to find a sufficiently large area with continuous and homogeneous sediment or rock bodies without fractures or preferential flow paths. (2) The geological deposits shall contribute to isolate the radioactive waste. This is most effective if the disposal site is underlain or surrounded by low permeability layers such as clay, silt or crystalline rock. (3) Restriction of pore water flow from the disposal site is favoured by deposits of low permeability. (4) The disposal site must be placed at the greatest possible distance from the nearest groundwater aquifer. (5) The disposal site must be located outside areas of special drinking-water interests. (6) The surrounding groundwater aquifer must be able to contribute to dilution of any radioactive material that might leak from the disposed material. (7) The surrounding sediments, rocks and ground water aquifer material must have a high potential for absorption of any leaking radioactive components. (8) Geological processes at the terrain surface should not have any influence on the quality of the disposal site.

\section{Criteria and methods for selection}

The potential disposal areas fit the criteria set up by Gravesen et al. $(2010,2011)$ to various degrees. Due to the heterogeneous geological conditions in Denmark it is not possible to fulfil all the criteria within one area. Therefore, it is necessary to assess the criteria and to compare the areas.

Criteria - The geological and hydrogeological criteria have been central for the selection of the areas. The type of disposal site had not been decided when the study started and the following criteria were considered the most important: (1) The deposits from the ground surface and downwards should be as homogeneous and of as low permeability as possible. This means that highly permeable deposits such as sand and gravel should be of limited extent. (2) The deposits of low permeability that enclose the waste should comprise thick layers of large horizontal extent. 
Other criteria were also important for the selection: (1) Areas of special drinking-water interests have been totally avoided. Areas of drinking water interests comprise a large part of Denmark and it was impossible to totally exclude these areas. (2) We tried to avoid groundwater bodies of good status. (3) EU nature protection areas (NATURA 2000) were completely avoided; other nature and heritage protection areas were avoided if possible. (4) Large cities and suburbs of larger cities were also avoided.

Methods for selection - The methods used were as follows: (1) The geological conditions in Denmark have been evaluated based on existing data and information (e.g. Pedersen 1989, Håkansson \& Pedersen 1992). It was decided which types of sediments and rocks should be included in the work. The sediments and rocks fulfilling most of the demands are: Crystalline rocks (granite and gneiss), some types of limestone, fine-grained pre-Quaternary clay and fine-grained Quaternary clay. If possible, layers of clayey tills should cover these deposits. (2) The next step was to identify and avoid the areas of special drinking-water interests, NATURA 2000 areas and large cities; these areas were not treated further. (3) The remaining areas were analysed according to the criteria of thick deposits of low permeability with large horizontal extent from the ground surface and downwards.

Possible future climate changes were also considered during the selection process. The current prognoses from the Intergovernmental Panel on Climate Change cover c. 100

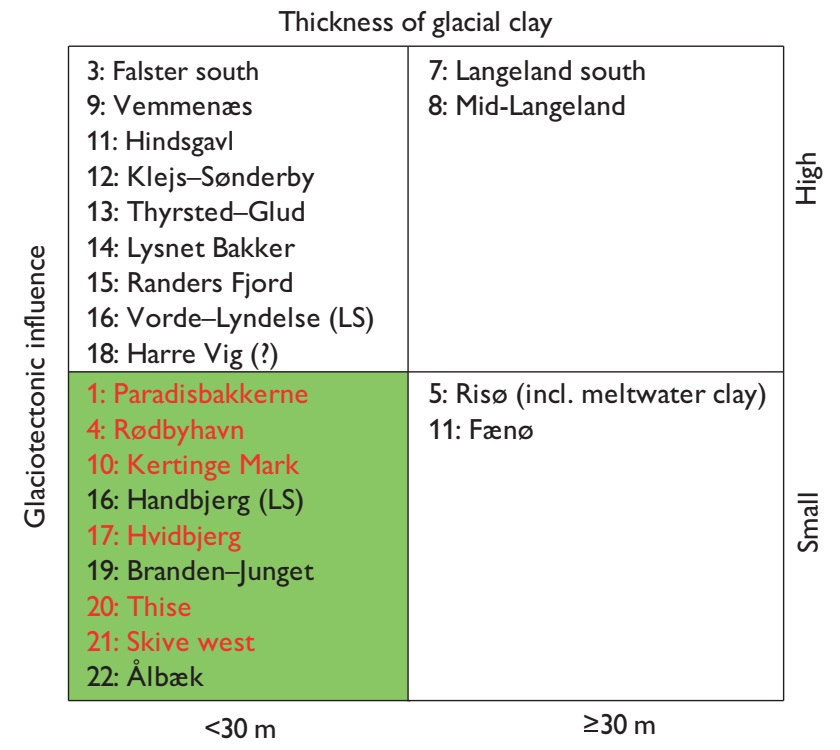

Fig. 2. Diagram showing the thickness of glacial clay (mainly clayey till) versus the importance of glaciotectonic influence. The green box show the best localities and the red localities are the selected ones. LS: Limfjord south. years. The waste facility must exist for at least 300 years; predictions of climate changes for the latter part of this period are highly uncertain. The sea level is expected to rise $0.5-1.0$ $\mathrm{m}$, but it may rise more.

\section{Survey results}

Our survey resulted in the selection of 22 areas throughout Denmark (Fig. 1). The compilation and scientific evaluation of the data resulted in several new findings concerning the Danish geology. Data from a large number of boreholes have been compiled from areas that normally attract little interest from geologists and water-resource managers. In addition, the selected areas are of no or little interest for local drinkingwater exploitation, nature protection or archaeology.

The selected areas are larger than required for the final depository. Therefore the final site can be located according to other limitations or parameters within the selected area.

From 22 to six areas - It is suggested that the work of the next phase be concentrated on six areas, chosen from among the 22 areas. The 22 areas were chosen so that they fulfil the criteria or most of the criteria. They are all qualified areas, according to an evaluation based on existing data and knowledge, but the amount of information and knowledge varies from area to area. The six areas are assessed as being slightly better than the remaining 16 areas, which are reserve areas that can be included if the six areas cannot be used for some reason

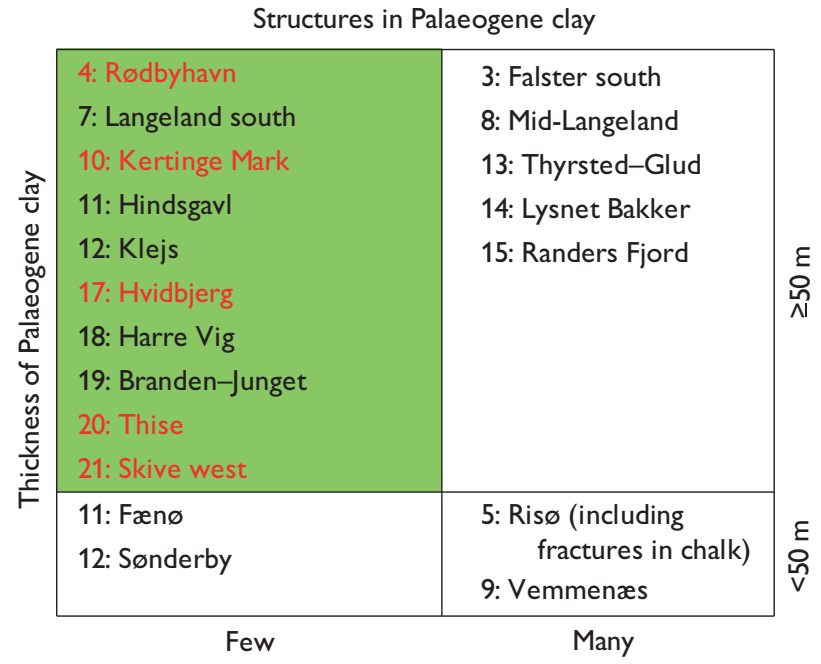

Fig. 3. Diagram showing the structures in Palaeogene clay versus the thickness of Palaeogene clay. The green box show the best localities and the red localities are the selected ones with Palaeogene clay, the sixth locality is in crystalline rock (Østermarie-Paradisbakkerne). The localities HammerenVang and Stevns are not shown in the diagrams, because they have no Palaeogene clay or they have not been influenced by glaciotectonics. 
that 'overrides' the geological criteria. The overriding factors could be grounded in infrastructure and regional planning as well as protests from citizens. Results from future detailed field and laboratory studies may also lead to the rejection of some areas, which were considered suitable according to existing knowledge.

The six areas are Østermarie-Paradisbakkerne in Bornholm's Regionskommune, Rødbyhavn in Lolland Kommune, Kertinge Mark in Kerteminde Kommune, Hvidbjerg in Struer Kommune, Thise in Skive Kommune and Skive west also in Skive Kommune (Fig. 1).

The geological criteria used to select the six potential areas were: (1) The areas have clay or crystalline rocks of low permeability from the ground surface to at least $100 \mathrm{~m}$ depth with only few subsurface structures. (2) Clayey till dominates the upper part, but this covering layer of clayey till is relatively thin (less than $30 \mathrm{~m}$ ) in most of the area, and layers of low permeability are rapidly reached. This meets the requirements for a medium deep repository $(30-100 \mathrm{~m})$, where the depository should be surrounded by layers of low permeability. (3) Glaciotectonic influence has little significance (down to $30 \mathrm{~m}$ ) but this is often difficult to assess for a large area, because glaciotectonic features can only be demonstrated from outcrop or borehole data. (4) In the selected areas, only areas of no, limited or some drinking-water interests are found. (5) In the areas, there are no significant occurrences of groundwater bodies with good status. (6) The terrain is mostly flat and of little relief, and the landscape is considered stable and without risk of landslides.

The different properties of the 22 areas were compared. Areas with glacial till less than $30 \mathrm{~m}$ thick and Palaeogene clay over $50 \mathrm{~m}$ thick were considered the best areas (Figs 2, 3). Also areas with only minor glaciotectonic influence and areas with only few tectonic structures in the Palaeogene clay were ranked as best. Areas with glaciotectonic deformations such as fractures, faults and folds (Klint \& Gravesen 1999) are often characterised by sand and gravel occurring between finer grained layers. With respect to tectonic structures in the Palaeogene clay, it should be noted that some areas are poorly covered by data.

As far as possible, the selected areas are located in regions with limited or no drinking-water interests. However, some of the selected areas are located partly or wholly in areas of drinking- water interests.

Six of the areas are located in areas with Quaternary clay, basement rock or chalk/limestone and do not include Palaeogene clay. These areas have relatively thin top layers of clayey till (less than $20 \mathrm{~m}$ ). Fractures and tectonic structures may occur. Based on our analysis of the properties we conclude that the six named areas are better suited for radioactive waste disposal than the other 16 areas.

\section{Final remarks}

Our survey resulted in the selection of 22 areas throughout Denmark. Six of these areas are preferred on geological and hydrogeological criteria. Eventually, the six areas will be reduced to one, two or three areas that appear promising in which further detailed field work will be carried out. The field investigations include analysis of the geological, hydrogeological, hydrochemical and geomechanical conditions. Finally, one site will be chosen for the final waste disposal.

\section{Acknowledgement}

Financial support was provided by the Parliament of Denmark.

\section{References}

Gravesen, P., Nilsson, B., Pedersen, S.A.S. \& Binderup, M. 2010: Low- and intermediate radioactive waste from Risø, Denmark. Location studies for potential disposal areas. Report no. 1. Data, maps, models and methods used for selection of potential areas. Danmarks og Grønlands Geologiske Undersøgelse Rapport 2010/122, 47 pp.

Gravesen, P., Nilsson, B., Pedersen, S.A.S. \& Binderup 2011: Low- and intermediate radioactive waste from Risø, Denmark. Location studies for potential disposal areas. Report no. 11. Områdebeskrivelser - Description of areas. Dansk og engelsk resume. Danmarks og Grønlands Geologiske Undersøgelse Rapport 2011/51, 64 pp.

Håkansson, E. \& Pedersen, S.A.S. 1992: Geologisk kort over den danske undergrund. 1:500 000. Copenhagen: Varv. (Map sheet).

IAEA 1994: Siting of near surface disposal facilities. Safety guides. Safety Series 111-G-3.1, 37 pp.

IAEA 1999: Near surface disposal of radioactive waste. Requirements. Safety Standards Series WS-R-1, 29 pp.

IAEA 2005: Borehole facilities for the disposal of radioactive waste. Specific safety guide. Safety Standards Series SSG-1, 102 pp.

Indenrigs- og Sundhedsministeriet 2007: Beslutningsgrundlag for et dansk slutdepot for lav- og mellemaktivt affald, $47 \mathrm{pp}$. Unpublished report, Indenrigs- og Sundhedsministriet, Copenhagen, Denmark.

Klint, K.E.S. \& Gravesen, P. 1999: Fractures and biopores in Weichselian clayey till aquitards at Flakkebjerg, Denmark. Nordic Hydrology 30, 267-284.

Ministry of Health and Prevention 2009: Redegørele om beslutningsgrundlag for et dansk slutdepot for lav- og mellemaktivt affald, 13 pp. Report, Ministry of Health and Prevention, Copenhagen, Denmark.

Pedersen, S.A.S. (ed.) 1989: Jordartskort over Danmark 1:200 000. Four map sheets: Nordjylland; Midtjylland; Sydjylland; Fyn, Sjælland, øer og Bornholm. Copenhagen: Danmarks Geologiske Undersøgelse. 